\title{
Incidence of myiasis in Panama during the eradication of Cochliomyia hominivorax (Coquerel 1858, Diptera: Calliphoridae) (2002-2005)
}

\author{
Sergio E Bermúdez/+, José D Espinosa*, Angel B Cielo*, Franklin Clavel*, \\ Janina Subía*, Sabina Barrios*, Enrique Medianero** \\ Sección de Entomología Médica, Instituto Conmemorativo Gorgas de Estudios de la Salud, PO Box 0816-02593, Panamá \\ *Comisión Panamá-Estados Unidos para la Erradicación y Prevención del Gusano Barrenador del Ganado, Panamá \\ **Programa Centroamericano de Maestría en Entomología, Universidad de Panamá, Panamá
}

We present the results of a study on myiasis in Panama during the first years of a Cochliomyia hominivorax eradication program (1998-2005), with the aim of investigating the behavior of the flies that produce myiasis in animals and human beings. The hosts that registered positive for myiasis were cattle (46.4\%), dogs (15.3\%), humans (14.7\%), birds (12\%), pigs (6\%), horses (4\%), and sheep (1\%). Six fly species caused myiasis: Dermatobia hominis (58\%), Phaenicia spp. (20\%), Cochliomyia macellaria (19\%), Chrysomya rufifacies (0.4\%), and maggots of unidentified species belonging to the Sarcophagidae (3\%) and Muscidae (0.3\%). With the Dubois index, was no evidence that the absence of $\mathrm{C}$. hominivorax allowed an increase in the cases of facultative myiasis.

Keys words: myiasis - Calliphoridae - Sarcophagidae - Oestridae - Panama

The term myiasis refers to the infestation by larvae of certain families of Diptera on alive vertebrates, that use these hosts for their development and cause various pathologies depending on the species that induce them (Acha \& Szyfres 2003). The causative species could be obligate parasites that depend exclusively on live vertebrates (primary myiasis); facultative parasites that can develop in decomposing matter as well in live animals (secondary myiasis); and species that cause accidental myiasis (Leclercq 1995, Stevens \& Otranto 2002).

In the Americas, the main investigations of myiasis have been made on obligate parasitic species such as Cochliomyia hominivorax and Dermatobia hominis, because of their great impact on human and animal health on the economies of many countries (Phillips et al. 2004). The results of these investigations were used to establish successful control plans, including the program to eradicate $C$. hominivorax in the United States, Mexico, and Central America (Moya 2003).

We estimate that in the Neotropics non-obligatory myiasis is caused by approximately 25 species of flies, 10 of which can be considered to cause accidental myiasis (e.g. some species of Syrphidae) and seven facultative (e.g. some species of Sarcophagidae and Calliphoridae) demonstrating the diversity of these groups (Méndez 1981, Oliva 2002). However, few data exist that demonstrate their incidence in the region, because only isolated cases have been recorded, and no investigations have been carried out to assess their ecological impact (Méndez 1981).

+Correspondig autor: sbermudez@ gorgas.gob.pa Received 18 December 2006

Accepted 11 June 2007
Given present factors, such as world-wide commerce and climate change, it is very important to carry out surveys in regions around the world to determine species diversity in families whose members can cause myiasis. The new knowledge will allow establishment of control plans, reporting foreign facultative species, and recording changes in their behavior. This information will be important since Native American species, such as $C$. hominivorax and D. hominis, are found in Africa (Krafsur \& Lindquist 1996) and in Europe (Leclerg 1995). Similarly an African species of Calliphoridae Cordylobia anthropophaga has been brought to Europe by travelers returning from Africa (Fox et al. 1992, Alkorta et al. 2001).

In this paper we report myiasis in Panama from 1998 through 2005, period of eradication of $C$. hominivorax. We also report to results of an evaluation of the shortterm empty niche effect, and present early data on the behavior of native and introduced fly species implicated in facultative myiasis.

\section{MATERIALS AND METHODS}

Data collection - As part of C. hominivorax eradication activities in Panama, in 1998 the Panama-United States Commission for the Eradication and Prevention of the Screwworm (COPEG, by the Spanish acronym), began a national myiasis monitoring program, which consisted of sampling myiasis infections in cattle poultry, farms, veterinary clinics, and wild animals throughout the republic, and in addition, human myiasis identified at health institutions. Samplings were take by veterinary personnel, working at farms and owners of pets, who collected larvae found in skin, natural openings, and wounds. The data for the years 1998-2005 were analyzed to genus. It is important to emphasize that during the years 1998 through 2002, species other than C. hominivorax were not identificate, and that beginning with the year 2003, all myiasis were identified. 
Statistical analysis - Data were organized in Microsoft Excel ${ }^{\circledR}$, and included qualitative variables such as date, province, hosts and fly species for each reported case. A simple regression analysis was carried out to verify the relationship between the number of $C$. hominivorax cases and those caused by other flies species for each year of study from 1998 through 2005.

Fly species behavior was analyzed using the fluctuation index of Dubois (Guisando et al. 2006), that quantifies population fluctuations in each fly species over time, and how they respond to changes in several factor (in this case, eradication of $C$. hominivorax). If the analysis gave values near zero, indicate no response to factor to investigate.

In order to establish the relationships between each species of fly and its host, and to verify interactions between them, we carried out an analysis of simple correspondence, based on the calculation of Chi-square analysis for contingency Tables, according to Peña (2002). This analysis compared preferences among the flies inducing myiasis for particular sets of host. The analyses were made with the XL-Stat program version $4^{\circledR}$.

\section{RESULT}

During the years 1998 through 2005, 19,897 cases of myiasis were registered, of which 15,245 corresponded to $C$. hominivorax and 4652 to other fly species (Fig. 1). Of these, $95 \%$ of the myiasis caused by $C$. hominivorax corresponded to the first years of the eradication program and was evident as a linear relationship between the increase of myiasis cases caused by other species and years $(\mathrm{F}=23 ; \mathrm{p} 0.05 ; \mathrm{r}=0.616$, and $\mathrm{r} 2=0.38)$.

For the years 2002 to 2005, 2497 cases of myiasis were registered, and attributed to: D. hominis $(57.9 \%)$, Phaenicia spp. (19.6\%), C. macellaria (19.3\%), and C. rufifacies $(0.4 \%)$ and none to $C$. hominivorax. In addition, we found maggots identified as Sarcophagidae $(2.5 \%)$ and Muscidae $(0.3 \%)$ (Table I, Fig. 2). These larvae were recovered from cows $(46.4 \%)$, dogs $(15.3 \%)$, humans $(14 \%)$, chickens $(11.9 \%)$, pigs $(5.8 \%)$, horses

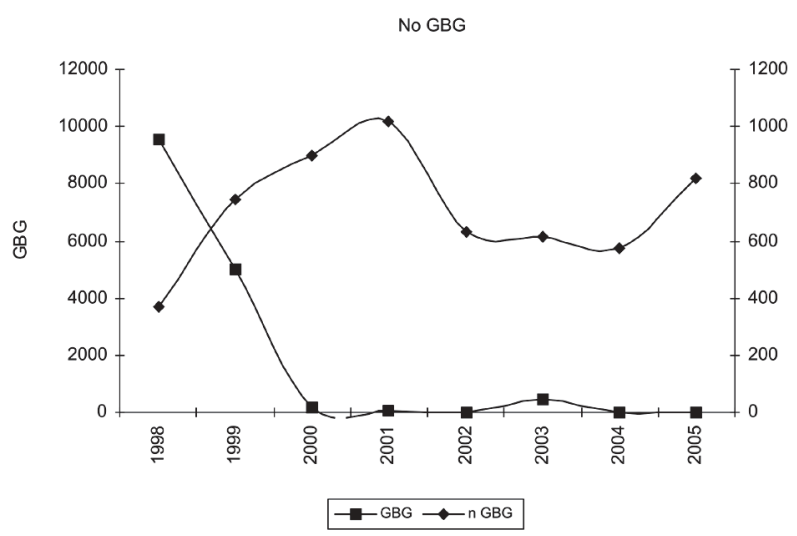

Fig. 1: occurrence of the cases of myiasis produced by Cochliomyia hominivorax and other species in Panama between years 1998-2005. GBG: refer to $C$. hominivorax; no GBG: others species.
(3.5\%), and sheep (1\%) (Table I, Fig. 3). A correspondence analysis indicates association between the species producing myiasis and their hosts (Chi-square analysis $=1385.05 ; \mathrm{p}<0.01 ; \mathrm{GL}=42)($ Fig. 4) and shows $96 \%$ variance.

When establishing the index of population fluctuation (Dubois index), it was demonstrated that the myiasis causing species had stable behavior during the years 20022005 , presenting values that were near zero, indicating that cases of myiasis did not vary during the study years, even after the eradication of $C$. hominivorax (Table II).

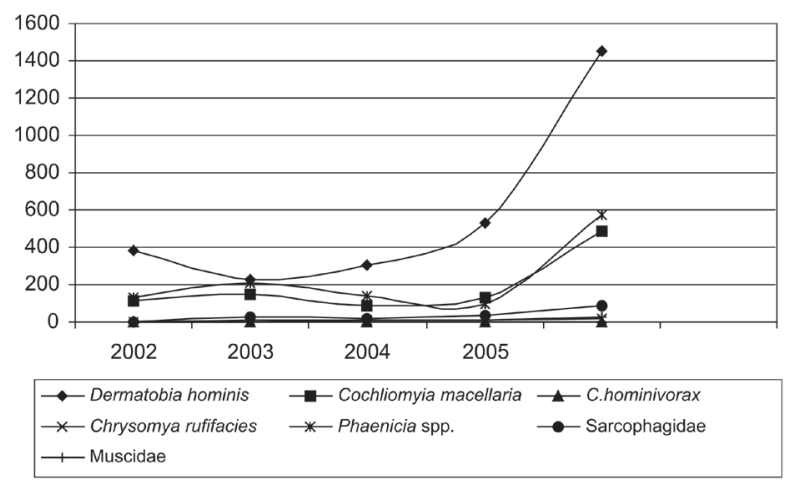

Fig. 2: fluctuation of the incidence of the species causes of myiasis in Panama during years 2002 to 2005.

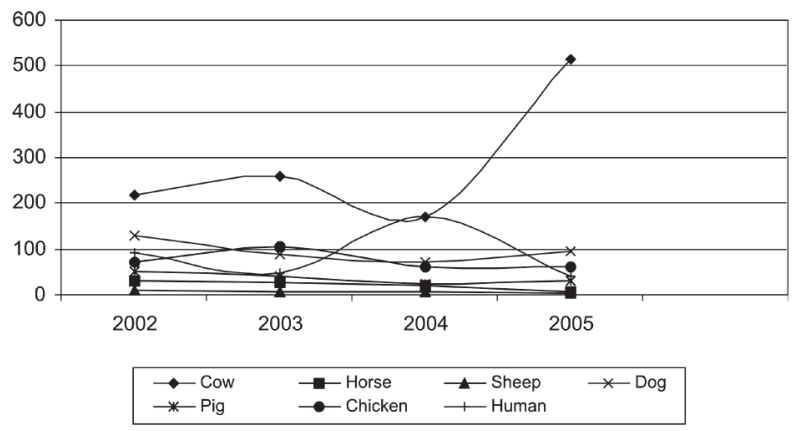

Fig. 3: incidence of myiasis by hosts in Panama, during years 2002 to 2005.

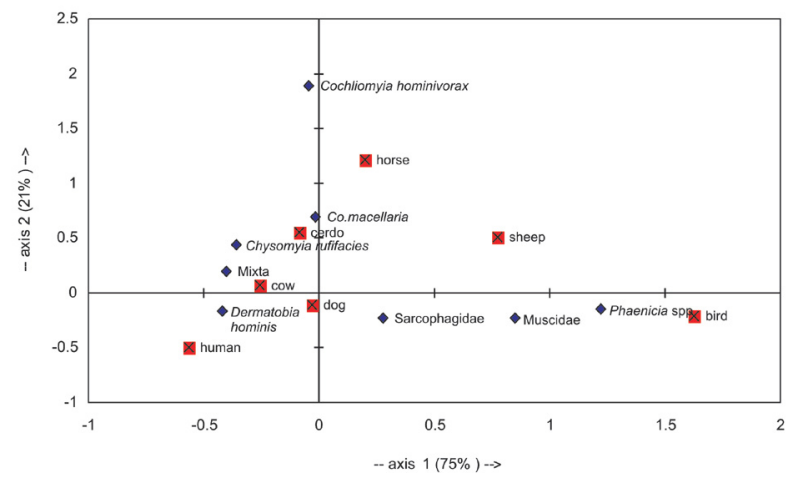

Fig. 4: analysis of simple correspondence between the inductive species of myiasis and their hosts in Panama during years 2002-2005; row profiles and column profiles on axes 1 and $2(96 \%)$. 
TABLE I

Number of cases of myiasis, inductive flies and their hosts, during years 2002-2005 in Panama

\begin{tabular}{|c|c|c|c|c|c|c|c|c|c|}
\hline \multirow[b]{2}{*}{ Year } & \multirow[b]{2}{*}{ Species } & \multicolumn{8}{|c|}{ Host } \\
\hline & & Cow & Sheep & Horse & Dog & Human & Pig & Chicken & Total \\
\hline \multirow[t]{6}{*}{2002} & Dermatobia hominis & 155 & 4 & 6 & 98 & 93 & 22 & 4 & 384 \\
\hline & Cochliomyia macellaria & 50 & 0 & 16 & 12 & 0 & 22 & 14 & 114 \\
\hline & Chysomyia rufifacies & 0 & 0 & 0 & 0 & 0 & 0 & 0 & 0 \\
\hline & Phaenicia sp. & 14 & 6 & 10 & 18 & 0 & 6 & 53 & 107 \\
\hline & Sarcophagidae & 0 & 0 & 0 & 0 & 0 & 0 & 0 & 0 \\
\hline & Muscidae & 0 & 0 & 0 & 0 & 0 & 0 & 0 & 0 \\
\hline \multirow[t]{6}{*}{2003} & D. hominis & 120 & 0 & 2 & 44 & 44 & 16 & 0 & 226 \\
\hline & C. macellaria & 77 & 2 & 22 & 18 & 0 & 18 & 10 & 147 \\
\hline & Ch. rufifacies & 2 & 0 & 2 & 0 & 0 & 0 & 0 & 4 \\
\hline & Phaenicia sp. & 57 & 4 & 0 & 24 & 2 & 4 & 87 & 178 \\
\hline & Sarcophagidae & 2 & 0 & 2 & 2 & 2 & 2 & 6 & 28 \\
\hline & Muscidae & 2 & 0 & 0 & 0 & 0 & 0 & 2 & 4 \\
\hline \multirow[t]{6}{*}{2004} & D. hominis & 89 & 0 & 6 & 37 & 164 & 8 & 0 & 304 \\
\hline & C. macellaria & 46 & 6 & 10 & 10 & 0 & 12 & 4 & 88 \\
\hline & Ch. rufifacies & 0 & 0 & 0 & 0 & 0 & 0 & 0 & 0 \\
\hline & Phaenicia sp. & 27 & 0 & 4 & 23 & 2 & 2 & 48 & 106 \\
\hline & Sarcophagidae & 6 & 0 & 2 & 0 & 4 & 2 & 6 & 20 \\
\hline & Muscidae & 0 & 0 & 0 & 0 & 0 & 0 & 2 & 2 \\
\hline \multirow[t]{7}{*}{2005} & D. hominis & 405 & 0 & 0 & 67 & 33 & 18 & 0 & 531 \\
\hline & C. macellaria & 75 & 2 & 8 & 18 & 0 & 6 & 0 & 133 \\
\hline & Ch. rufifacies & 8 & 0 & 0 & 0 & 0 & 2 & 0 & 10 \\
\hline & Phaenicia sp. & 20 & 2 & 0 & 10 & 2 & 4 & 61 & 99 \\
\hline & Sarcophagidae & 4 & 0 & 0 & 2 & 6 & 0 & 2 & 14 \\
\hline & Muscidae & 2 & 0 & 0 & 0 & 0 & 0 & 0 & 2 \\
\hline & Total & 1159 & 26 & 88 & 383 & 352 & 144 & 299 & 2497 \\
\hline
\end{tabular}

TABLE II

Index of population fluctuation of the inducing species of myiasis in Panama during years 2002 to the 2005

\begin{tabular}{cc}
\hline Year & Index \\
\hline 2002 & 0.08 \\
2003 & 0.12 \\
2004 & 0.01 \\
2005 & 0.06 \\
\hline
\end{tabular}

\section{DISCUSSION}

Our results demonstrate the presence of at least six species of flies that induce myiasis in Panama, of which D. hominis, C. macellaria, and Phaenicia spp., which maintenance a consistent incidence during the years of study. These results are similar to those reported by Oliveira et al. (2004), who found that $C$. hominivorax (30\% incidence), D. hominis (21\%), C. macellaria $(18 \%)$, and Sarcophagidae (12\%) were the species most associated with human myiasis in the Baixada Fluminense (Brazil). The data seem to demonstrate that, so far, the eradication of $C$. hominivorax has not favored the increase in myiasis caused by other fly species, confirmed by the low values in the Dubois index, due the values is near zero, indicate no response to factor to investigate.
It is important to emphasize that an important part of the eradication campaign is to show animal care-givers how to clean wounds, administer medications, and collect larvae. Nevertheless, when $C$. hominivorax cases diminish, especially in the western provinces of Panama, many cattle dealers and/or pet owners neglect the care of their animals, and the number of cases rises. This pattern was seen for the years 2001-2005.

Thus, although non $C$. hominivorax species showed no overall increased in case following the eradication, there was a change in species ratios: case of $D$. hominis increased to represent $60 \%$ of all myiasis cases (Figs 1, 2 ), and it appears that increased in case of this species represent an overall decrease in vigilance on the part of animal care-takers. D. hominis is an obligatory species that has horizontal mechanical transmission via eggs stage phoresis, that depends upon at least two variables: abundance of the phoretic population and contact of this population with man or other hosts. However, this latter variable was not evaluated. It is known that $D$. hominis has a broad host range, including mammals and birds, and in our study it parasitized all hosts sampled, although it occurred mainly in humans, bovines, and dogs. It is interesting to notice that D. hominis caused $95 \%$ of myiasis in humans and $66 \%$ in bovines. Parasitism by $D$. hominis in humans occurs mainly in suburban and rural areas where domestic cattle or animals are found near houses and to a lesser extent in urban areas when inhabitants visit rural or forested areas. 
With respect to the analysis of simple correspondence many hosts attract specific fly species or related fly species. For example, we found that $83 \%$ of myiasis in birds was caused by larvae of Phaenicia spp. Until now the idea of co-evolution and specificity of hosts in Calliphoridae and Sarcophagidae did not exist (with the exceptions of the association of Lucilia bufonivora and Notochaeta bufonivora with Anura, and N. carolensis and Cistudinomyia cistudinis with reptiles) leading us to believe that the flies respond opportunistically to hosts that occur in large numbers (in this case the parasitism of poultry by Phaenicia). The idea of opportunistic host selection was supported by the finding that species considered to be facultative, as Lucilia (= Phaencia) cuprina and $L$. sericata, inflict economic casualties in sheep in various countries, including the United Kingdom, Australia, and New Zealand (Heath \& Bishop 2006). The selection of desirable characteristics in domestic animals can be accompanied by changes in the defense mechanisms of the animals, making them more susceptible to parasitism (Stevens \& Wallman 2006). In the same way, stress caused by confining many animals in small areas, together with their organic waste, a practice common in poultry breeding, provides appropriate conditions for fly population increases.

C. macellaria was found to cause $16 \%$ of all cases of myiasis in all hosts sampled. This species, considered the secondary screwworm of the New World, lays eggs especially on decomposing animal material, and may, under suitable conditions, invade wounds in live animals and man (Harwood \& James 1987). Myiasis by C. macellaria has been documented by Oliva (2002) in Argentina and by Oliveira et al. (2004) in Brazil.

C. rufifacies was observed in low numbers on a variety of hosts. This species is the most common in animal and human carcasses, where third stage larvae are predators on other species larvae, and it has been reported to attack living animals (Heath \& Bishop 2006), and therefore they can become a serious problem (Harwood \& James 1987). In Panama, in addition to C. rufifacies, two other species, C. megacephala and C. chloropyga, have been reported (Bermúdez 2007), the first of which was found causing myiasis in dying humans (Sukontason et al. 2005).

The genus Chrysomya is native to the Old World but dispersed to the Americas during the 1970s (Guimãraes et al. 1978). It is possible that the first confirmed report of the myiasis caused by this genus in America was made by Richard and Gerrish (1983), who described a case of myiasis by $C$. rufifacies in a dog in the United States. Later that species was reported to attack human beings in Brazil (Oliveria et al. 2004). It is important to emphasize that $C$. bezziana, which also belongs to this genus, is the ecological equivalent of $C$. hominivorax in the Old World (Lee et al. 2005). That species has not been reported in the Americas; nevertheless many regions have biogeographic characteristics that potentially could favor its establishment (Sutherts et al. 1989).

The incidence of myiasis by Muscidae and Sarcophagidae was low during the study. A number of species of Muscidae have been associated with cases of myiasis in the presence of poor hygiene in countryside or suburban settings (Méndez 1981). Additionally they have been reported to cause enteric and urogenital myiasis (Harwood \& James 1987, Acha \& Szyfres 2003). Some genera of Muscidae are obligate parasites with a tight relationship with their hosts, for example, Neomusca and Philornis with birds (Couri \& Carvalho 2003). Concerning myiasis by Sarcophagidae, one species was responsible for the majority of cases involving the auditory channel of children. The species responsible for these attacks probably was Wohlfahrtia spp. (observation of one of the co-authors). Flies of this genus have been reported to cause myiasis in Europe, Asia, and North America (Harwood \& James 1987, Acha \& Szyfres 2003). Unfortunately the taxonomy of this family is not clear, making identifications difficult, and preventing us from cataloging and understanding the behavior of Panamanian species.

\section{ACKNOWLEDGEMENTS}

To Grace Alpízar and Anayansi Valderrama for their comments and Annette Aiello and Nicanor de Obaldía III for correction in English.

\section{REFERENCE}

Acha PN, Szyfres B 2003. Zoonosis y Enfermedades Transmisibles Comunes al Hombre y los Animales, 3rd ed., OPS Pub. Cient. Tec. No. 80, 412 pp.

Alkorta M, Beristain X, Cilla G, Tuneu A, Zubizarreta J 2001. Myiasis cutánea por Cordylobia anthropophaga. Rev Esp Salud Pub 75: 23-30.

Bermúdez SE 2007. Listado preliminar de la familia Calliphoridae (Diptera: Oestroidea) en Panamá. Tecnociencia 9: 101-112.

Couri MS, Carvalho CJ 2003. Systematic relations among Philornis Meinert, Passeromyia Rodhain \& Villeneuve and allied genera (Diptera: Muscidae). Braz J Biol 63: 223-232.

Fox MT, Jacobs DE, Hall MJ, Bennett MP 1992. Tumbu fly (Cordylobia anthropophaga) myiasis in a quarantined dogs in England. Vet Record 1: 100-101.

Guimãraes J, do Prado AP, Linhares AX 1978. Three newly introduced blowflies species in Southern Brazil (Diptera: Calliphoridae). Rev Bras Entomol 22: 53-60.

Guisando CG, Barreiro A, Maneiro I, Riveiro I, Vergara AR, Vaamonde A 2006. Tratamientos de Datos, Días de Santos, España, 356 pp.

Harwood RF, James MT 1987. Entomología Médica y Veterinaria, Limusa, España, 615 pp.

Heath AC, Bishop DM 2006. Flystrike in New Zealand: an overview based on a 16 year study, following the introduction and dispersal of the Australian sheep blowfly, Lucilia cuprina Wiedemann (Diptera: Calliphoridae). Vet Parasitol 137: 333-344.

Krafsur ES, Lindquist DA 1996. Did the sterile insect technique or weather eradicate screwworms (Diptera: Calliphoridae) from Lybia? J Med Entomol 33: 877-887.

Leclercq M 1995. Myiase cutanée furonculoide humaine par Dematobia hominis (Linnaeus 1781) (Diptera: Cuterebridae). Una observation en Belgique. Bull Ann Soc R Belge Ent 131: 327-334. 
Lee HL, Krishnasamy M, Jeffery J 2005. A case of human nasopharyngeal myiasis caused by Chrysomya bezziana Villeneuve 1914 (Diptera: Calliphoridae) in Malasya. Trop Biomedicine 22: 87-88.

Méndez E 1981. Las myiasis centroamericanas y los dipteros que las producen. Rev Med Panamá 6: 146-158.

Moya GE 2003. Erradidacaçao ou manejo integrado das miíases neotropicais das Américas. Pesq Vet Bras 23: 131-138.

Oliva A 2002. Myiasis en la Argentina. In Actualizaciones en artropología sanitaria argentina. Monografía 2, p. 45-50.

Oliveira JT, Oliveira BM, Gonçalves AS, Serra-Freire NM 2004. Ocurrencia de myiasis humanas na região da Baixada Fluminense, Estado do Rio de Janeiro, Brasil. Entomol Vec 11: 85-102.

Peña D 2002. Análisis de Datos Multivariantes, McGraw Hill, Madrid, 539 pp.

Phillips PL, Welch JB, Kramer M 2004. Seasonal and spatial distributions of adults screwworms (Diptera: Calliphoridae) in the Panama Canal Area, Republic of Panama. J Med Entomol 41: 121-129.
Richard RD, Gerrish RR 1983. The first confirmed field case of myiasis produced by Chrysomya sp. (Diptera: Calliphoridae) in the continental United States. J Med Entomol 20: 685.

Stevens JR, Otranto D 2002. Patterns of evolution in myiasiscausing Calliphoridae and Oestridae and the evolution of parasitism. In Proceedings of EU-COST action 833: mange and myiasis of livestock, p. 199-203.

Stevens JR, Wallman JF 2006. The evolution of myiasis in human and others animals in the Old and New Worlds (part I): phylogenic analyses. Trends Parasitol 22: 129-136.

Stevens JR, Wallman JF, Otranto D, Wall R, Pape T 2006. The evolution of myiasis in human and others animals in the Old and New Worlds (part II): biological and life-history studies. Trends Parasitol 22: 182-188.

Sukontason K, Narongciial P, Sripakdee P, Ciiaiwong T, NgernKlun R, Sukontason K 2005. First report of human myiasis caused by Chrysomyia megacephala and Chrysomyia ruficacies (Diptera: Calliphoridae) in Thailand, and its implication in forensic entomology. J Med Entomol 42: 702-704.

Sutherts RW, Spradbery GF, Maywald GF 1989. The potential geographic distribution of the Old World screwworm fly, Chrysomya bezziana. Med Vet Entomol 3: 273-280. 
